\title{
Anti-Inflammatory Treatment of Asthma
}

\author{
Klaus F. Rabe, MD, PhD, FERS
}

LungenClinic Grosshansdorf \& Dept of Medicine, Christian Albrechts University Kiel, Members of the German Center for Lung Research (DZL), Großhansdorf, Germany

\section{ABSTRACT}

Bronchial asthma is an inflammatory disease of the airways affecting individuals of all ages. Pharmacotherapy relies on bronchodilator drugs, usually in combination with inhaled corticosteroids, with the clinical aim to reduce symptoms, improve lung function, and prevent exacerbations. While these principle approaches, together with measures of allergen avoidance and secondary prevention, improve and control the disease in a majority of patients, a significant number of asthmatics remain symptomatic, especially in severe disease. Furthermore, there is increased recognition of a large variability of asthma phenotypes, with different clinical course but also with a variety of distinct inflammatory mechanisms. This has led to the development of novel anti-inflammatory medicines, some of which target specific inflammatory pathways in asthma with high selectivity. These novel drugs will hopefully benefit those patients with more severe disease and underlying inflammation that is not adequately responding to standard asthma therapies. (BRN Rev. 2016;2:56-68) Corresponding author: Klaus F. Rabe, k.f.rabe@lungenclinic.de

Key words: Asthma. Human. Inflammation. Personalized medicine. Therapy. 


\section{INTRODUCTION}

Asthma is an important chronic disease, affecting more than 300 million individuals of all ages $^{1}$. In recent years, the views on the immunology of asthma have changed considerably. Once believed to be predominantly a $\mathrm{T}$ helper type 2 (Th2) inflammatory disease of the airways, it is now becoming clear that various endotypes of this disease exist, giving way to the development of novel anti-inflammatory drugs that target this disease heterogeneity specifically ${ }^{2}$.

Conventional management of asthma according to guidelines involves non-pharmacological approaches, such as allergen avoidance, and pharmacotherapy ${ }^{3}$. Regular inhaled corticosteroids (ICS) combined with long-acting $\beta_{2}$ agonists (LABA) are the mainstay of asthma treatment for a vast majority of patients and for most severity grades. Patients who are not sufficiently controlled on this combination therapy might be tried on other controller drugs such as leukotriene-receptor antagonists, theophylline, and the addition of long-acting anticholinergics has been advocated for more severe disease. Regular treatment with oral corticosteroids can be advisable in some patients with severe disease, while treatment with the monoclonal anti-immunoglobulin E (anti-IgE) antibody omalizumab may be indicated if there is an obvious allergic background in the clinical presentation. It is estimated that $5-10 \%$ of asthma patients are in need of such high-level treatments $^{4}$ in the context of severe asthma ${ }^{5,6}$.

This review will explicitly not reiterate data that form the basis of conventional therapy in clinical practice guidelines, but aims to highlight novel developments based on our current understanding of (severe) asthma pathophysiology $y^{7}$. This paper will focus on the role of a number of small proteins that drive the inflammatory processes and pathophysiological mechanisms of asthma. Most of the relevant proteins in asthma inflammation are interleukins (IL) or cytokines, and most of the novel anti-inflammatory therapies for severe asthma try to block the pathways involved. The development of some of such novel therapeutic agents has provided additional insights into the diversity of the inflammatory process in severe asthma and has helped define phenotypes that will specifically respond to specifically targeted treatment.

\section{AIRWAY INFLAMMATION AND ASTHMA TODAY}

The chronic inflammatory process in the airways of asthmatics is characterised by infiltration of the airway submucosa by a range of cells, including eosinophils, basophils, mast cells, and CD4 T-helper cells. The initiating components of this inflammation involve the airway epithelium, dendritic cells, and airway macrophages, responding to external environmental factors such as allergens, pollutants, and infectious (viral) triggers. These early events lead to the activation of further cells such as T-cells, B-cells, and mast cells, which in turn activate airway structural cells such as airway smooth muscle cells, mucus goblet cells, and fibroblasts ${ }^{8}$. Several cytokines have been described as promoters of chronic airway inflammation and remodelling ${ }^{9,10}$, either directly or by affecting and promoting cell-cell interactions ${ }^{11,12}$. T-helper-2 (Th2) cells and, more lately, type 2 innate lymphoid cells (ILC2) have been recognised as 


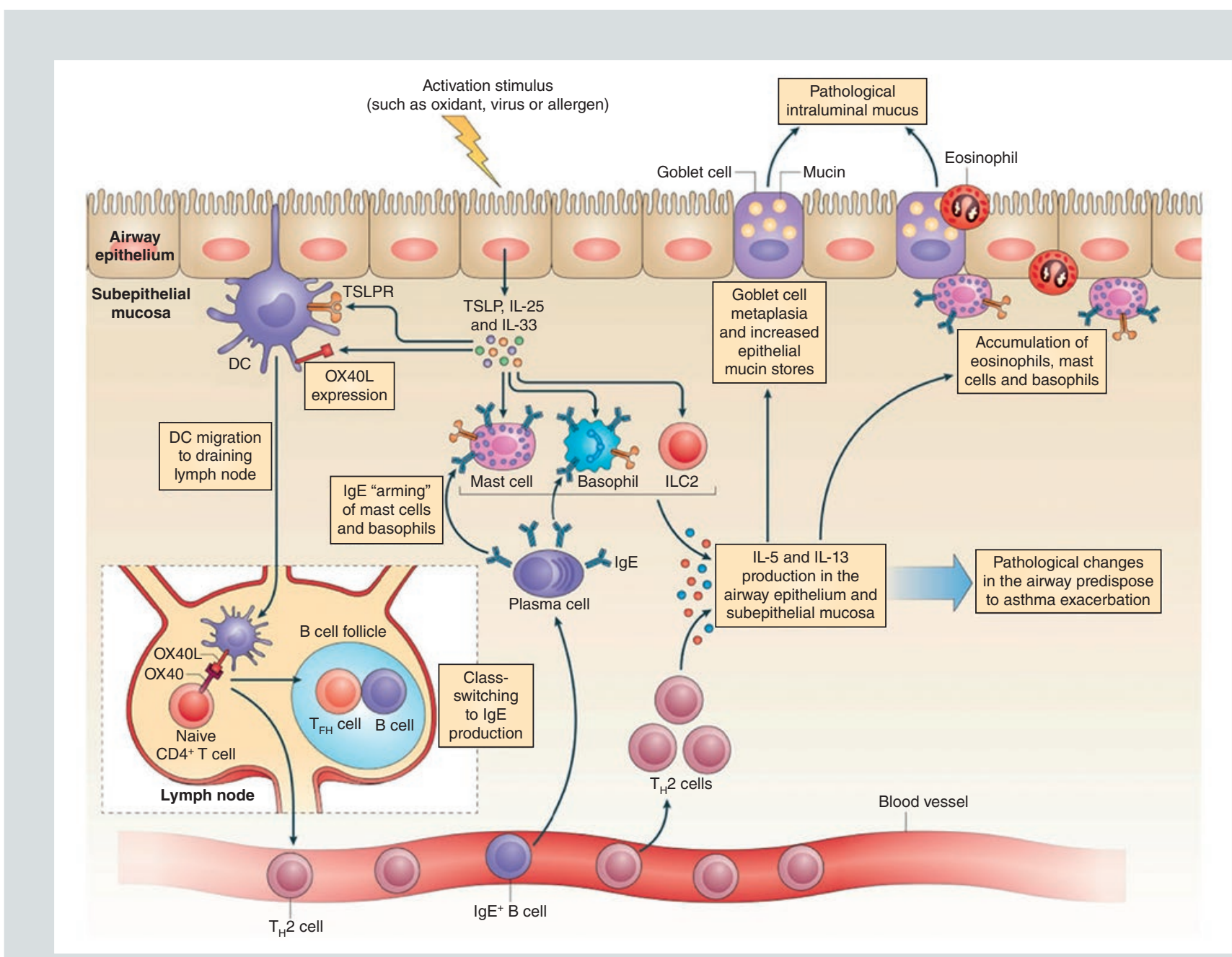

Figure 1. Type 2 immune response in asthma. Release of epithelial cell cytokines, such as interleukin-33 and thymic stromal lymphopoeitin, induce the expression of OX40 ligand (also known as TNFSF4) on dendritic cells to promote their mobilization to local draining lymph nodes. Interleukin-4-competent T-cells in the lymph nodes migrate to B-cell zones where they differentiate into T follicular helper cells and move into the circulation to complete maturation as T helper 2 cells. The T helper 2 cells that migrate to the airway epithelium and to the sub-epithelial mucosa secrete interleukin-5 and -13 to mediate inflammatory and remodelling changes in the airway mucosa that predispose an individual to asthma and to asthma exacerbations (adapted with permission from Fahy ${ }^{14}$ ).

DC: dendritic cell; igE immunoglobulin E; IL: interleukin; ILC2: group 2 innate lymphoid cell; 0X40L: 0X40 ligand; Tfh: T follicular helper cell; Th2: T helper 2 cell; TSLP: thymic stromal lymphopoeitin; TSLPR: TSLP receptor.

important drivers of eosinophilic asthma. They produce IL-4, IL-5, and IL-13, which in turn increase in IgE production and eosinophilic inflammation, while innate immune cytokines such as IL-1, IL-25, and IL-33, and thymic stromal lymphopoietin (TSLP) released from airway epithelial cells can also activate both Th2 cells or ILC2 cells (Fig. 1)9.
Asthma heterogeneity has long been recognised $^{13,14}$ and this phenotypic diversity is also reflected through different inflammatory and molecular mechanisms ${ }^{15}$. The Th2 cells have been recognised as an important part of asthmatic inflammation, and "Th2-high asthma" has been defined by use of genes expressed in airway epithelial brushings, consisting of a 


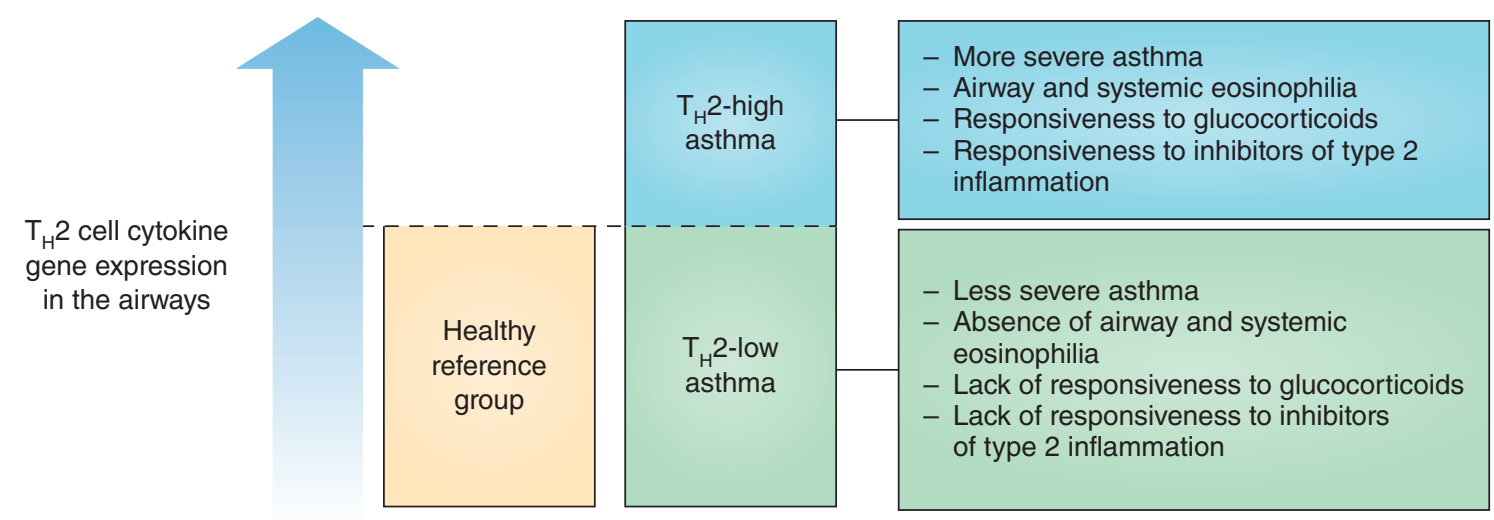

Figure 2. Asthma can be divided into T helper cell type 2 low and high subgroups (adapted with permission from Fahy ${ }^{14}$ ). Th2: $\mathrm{T}$ helper cell type 2

set of IL-13-inducible genes ${ }^{16}$. However, just half of a group of patients with mild-to-moderate asthma had a Th2-high asthma phenotype that was characterised by a greater degree of bronchial hyper-responsiveness, higher serum IgE concentrations, and increased blood and airway eosinophilia ${ }^{17}$. This seminal finding has led to the distinction of a Th2-high and a Th2-low endotype (Fig. 2) ${ }^{18}$.

This categorisation theoretically has implications for testing new compounds that target specific molecular pathways in the clinic, particularly in identifying patients most likely to respond to these treatments ${ }^{19}$. In early trials the anti-IL-5 antibody mepolizumab appeared ineffective in patients with asthma recruited solely according to severity ${ }^{20}$; only when patients with severe asthma and with a history of frequent exacerbations and eosinophilia in sputum or blood were investigated did the drug show a relevant reduction in exacerbations compared with placebo ${ }^{21}$.

\section{ANTI-INFLAMMATORY THERAPIES IN ASTHMA: BEYOND STEROIDS}

\section{The T helper cell type 2 pathway}

Activation of the Th2 pathway is a complex interaction between the innate and adaptive immune responses. It involves the differentiation of Th2 cells from uncommitted T-cells, and the action of co-stimulatory molecules and cytokines expressed by dendritic cells and inflammatory cells. Synthesis of cytokines, such as TSLP, IL-25, and IL-33 from the epitheli$\mathrm{um}^{28}$, can be induced by external stimuli such as lipopolysaccharide, pollutants, and virus$\mathrm{es}^{29}$ to activate of Th2 cells. The Th2 cells in turn release IL-4, IL-5, and IL-13, orchestrating inflammation in the airway mucosa of patients with asthma. Interestingly, Il-5 and IL-13 can also be produced by ILC2, which require globin transcription factor (GATA)-binding protein-3 (GATA-3) for their development and function (Fig. 3). 


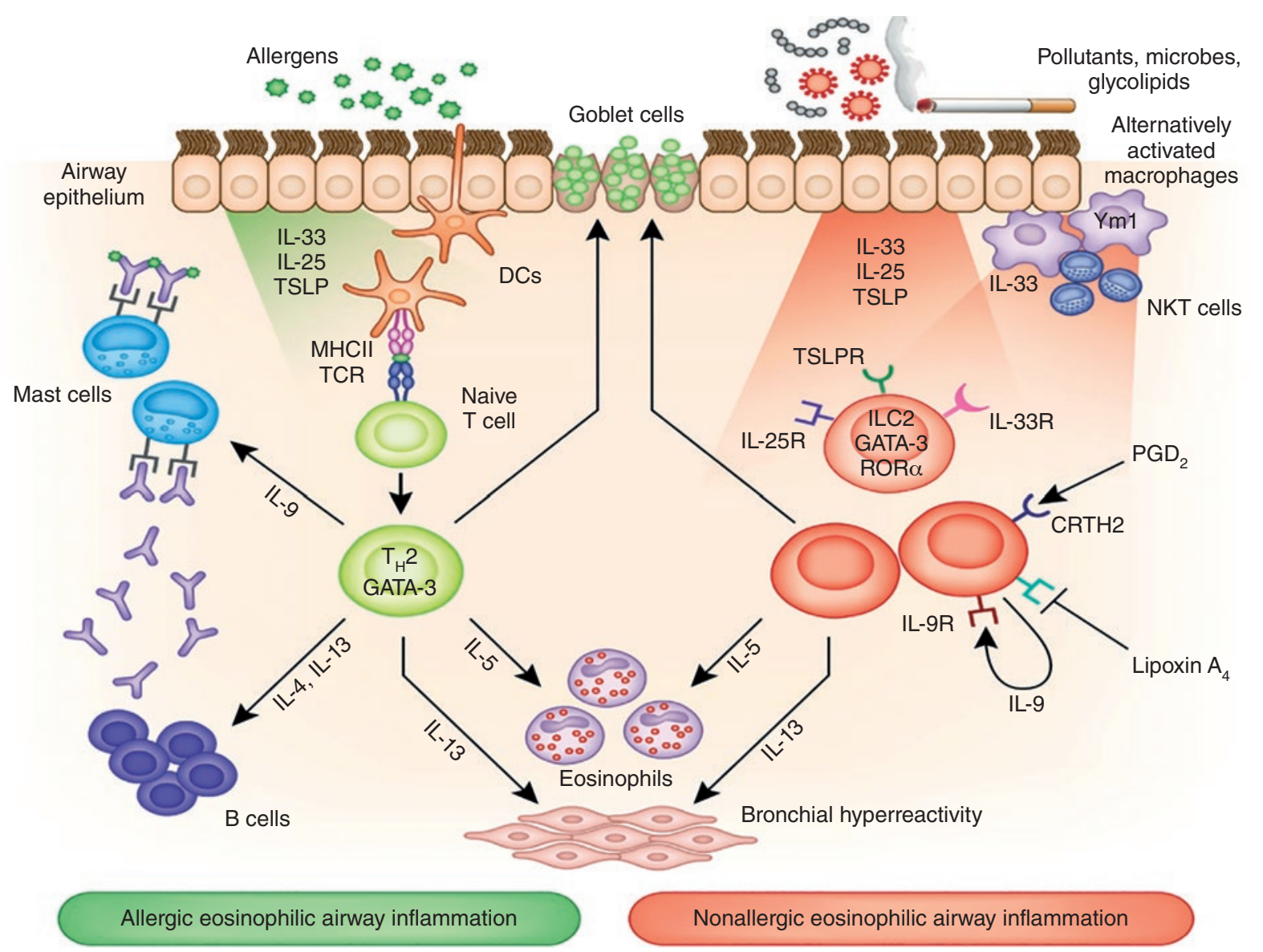

Figure 3. Relative roles of T helper type 2 cells and type 2 innate lymphoid cells in two forms of eosinophilic asthma. In atopic asthma (left), eosinophilic airway inflammation and bronchial hyper-responsiveness are driven by adaptive T helper 2 cells that are stimulated by dendritic cells to produce interleukin-5, -13 and -4 , the latter driving immunoglobulin E synthesis. In non-atopic or intrinsic asthma (right), which is not dependent on adaptive immunity, type 2 innate lymphoid cells produce interleukin- 5 and -13 and thus cause eosinophilia and bronchial hyper-responsiveness (reproduced with permission from Lambrecht et al. ${ }^{2}$.

CRTH2: chemoattractant receptor-homologous molecule expressed on Th2 cells; DC: dendritic cell; GATA: globin transcription factor; IL: interleukin; ILC2: type 2 innate Iymphoid cell; MHCII: major histocompatibility complex class 2; NK: natural killer; PGD: prostaglandin; ROR: retinoid-related orphan receptor; TCR: T-cell receptor; TSLP: thymic stromal lymphopoietin.

Immunoglobulin $\mathrm{E}$ ( $\mathrm{IgE}$ ) has a central role in allergic inflammation and is a result of the effect of IL-4 and IL-13 switching in immunoglobulin synthesis towards IgE from B-cells. The IgE-activated mast cells secrete interleukins, such as IL-3, IL-4, and IL-5, and granulocyte macrophage colony stimulation factor, which recruit or activate eosinophils.

\section{Targeting GATA-3}

GATA-3 is an important transcription factor in the Th2 pathway and has recently been targeted with SB010, a novel DNA enzyme ${ }^{22}$. In this first small placebo-controlled trial, subjects inhaled the DNA enzyme and were challenged with allergen. The SB010 attenuated 
both the early and late allergen response. Furthermore, the analysis of biomarkers revealed an attenuation of Th2-regulated inflammatory responses. As yet, no further clinical data have been released.

\section{Targeting immunoglobulin E}

Omalizumab is a humanised antibody that binds to the CE3 domain of the free circulating $\operatorname{IgE}$, resulting in a reduction in $\operatorname{IgE}$ available for binding to high-affinity IgE receptors (FceR1) and also a reduction in high-affinity FceR1 receptors present on mast cells and basophils $^{30}$. This interrupts the allergic cascade and prevents mast cell degranulation and reduces eosinophilic inflammation ${ }^{30,31}$. Clinically, omalizumab decreases early and late asthmatic responses, sputum and tissue eosinophil counts, and submucosal cells positive for IgE and Fc\&R1 ${ }^{32}$. The drug improved asthma-related quality of life measures and reduced exacerbation rates; improvements in forced expiratory volume in one second $\left(\mathrm{FEV}_{1}\right)$ in patients with moderate-to-severe asthma are small, however ${ }^{4,32}$. Omalizumab is recommended for severe persistent allergic asthma as an add-on therapy as it decreased clinically significant asthma exacerbations by $26 \%$ compared with placebo. A trial of omalizumab in both adults and children with severe allergic asthma is recommended if conventional treatment fails ${ }^{4}$, and therapeutic efficacy for omalizumab in reducing exacerbations seems related to high concentrations of nitric oxide ${ }^{23}$ in exhaled breath and high blood eosinophil counts ${ }^{33}$.

QGE031 (Novartis, Basel, Switzerland) is a humanised anti-IgE antibody with a 50-fold higher affinity for IgE than omalizumab ${ }^{34}$. QGE031 reduced circulating concentrations of $\operatorname{IgE}$, FceR1, surface IgE, and skin-prick responses to aeroallergens to a greater extent than omalizumab in allergic patients with well-controlled asthma, but the drug is not commercially available yet ${ }^{37}$.

\section{Targeting interleukins 4 and 13}

\section{ANTI-INTERLEUKIN-4 RECEPTOR ALPHA ANTIBODY}

Both IL-4 and IL-13 bind to the same receptor, a heterodimer of the $\alpha 1$ chain of the IL-13 receptor (IL-13R $\alpha 1$ ) and the $\alpha$ chain of the IL-4 receptor (IL-4R $\alpha 1)^{35}$.

Interleukin- 4 and -13 have important roles in Th2-cell differentiation from naïve T-cells, isotype class-switching of B-cells towards IgE synthesis mast cell recruitment. Interleukin-4 also up-regulates high-affinity $\mathrm{IgE}$ receptors on mast cells, and low-affinity receptors on B-cells and mononuclear phagocytic cells, while both interleukins up-regulate vascular cell adhesion molecules on endothelial cells, thus facilitating transmigration of eosinophils, $\mathrm{T}$ lymphocytes, monocytes, and basophils.

Interleukin-13 shares 30\% homology with IL-4 and in asthma the effects of IL-13 include increases in goblet cell differentiation, activation of fibroblasts, and an increase in bronchial hyper-responsiveness ${ }^{36}$.

Pitrakinra is a mutated form of human IL-4, with a high affinity for the IL-4 receptor, and acts as a competitive antagonist. In phase II trials, the drug attenuated the late-phase asthmatic response to allergen challenge in patients 
with mild atopic asthma ${ }^{37}$. No further development of pitrakinra in asthma was reported, maybe because a reduction in exacerbation frequency during withdrawal of ICS was reported only in specific subgroups of patients with eosinophilic asthma and raised exhaled nitric oxide concentrations, with a specific IL-4 receptor polymorphism ${ }^{38}$.

AMG 317 (Amgen, US), a human monoclonal antibody against IL- $4 \mathrm{R} \alpha$ that blocks both IL-4 and IL-13 pathways, did not show efficacy in patients with moderate-to-severe asthma. AMG 317 did not change Asthma Control Questionnaire (ACQ) scores from baseline and had no effect on exacerbations ${ }^{39}$.

Dupilumab (Regeneron, US) is a human monoclonal antibody that binds to IL-4R $\alpha$. It reduced asthma exacerbations and improved asthma control and lung function compared with placebo when LABA was discontinued and ICS dose reduced and stopped ${ }^{40}$ in patients with moderate asthma and with evidence of either sputum or blood eosinophilia. There was also an associated reduction in Th2-associated inflammatory markers, such as CCL17 (TARC), CCL26 (eotaxin-3) and IgE. In another phase II study of adults with uncontrolled asthma on medium-to-high dose ICS/ LABA, dupilumab improved $\mathrm{FEV}_{1}$ at week 12 in patients with raised blood eosinophil counts, although depending on the dosing scheme ${ }^{41}$.

\section{ANTI-INTERLEUKIN-4 ANTIBODY}

Unlike the IL-4/13 receptor antagonists, inhaled recombinant human soluble IL-4 receptor has been used to antagonise IL-4. Curiously, a single nebulised dose was shown to be effective in moderate asthma and was associated with improvement in $\mathrm{FEV}_{1}$ and improved asthma control ${ }^{56}$. In a 12-week dosing study, there was significant effect in preventing reduction in $\mathrm{FEV}_{1}$, but not on exacerbation rates following reduction of maintenance doses of ICS in moderate persistent asthma ${ }^{57}$ and benefits were reported in subsequent clinical trials. Development of this soluble IL-4 receptor for asthma apparently has stopped.

\section{ANTI-INTERLEUKIN-13 ANTIBODY}

Lebrikizumab (Genentech, US) is an IgG4 humanised monoclonal antibody that blocks binding of IL-13 to the IL-4R $\alpha$ and IL-13R $\alpha 1$ heterodimer. In patients with mild asthma, lebrikizumab did not statistically affect allergen responses, although numerically, a reduction of the late asthmatic response was noted compared with placebo $^{42}$. In patients with uncontrolled asthma despite use of ICS/LABA, treatment with lebrikizumab improved $\mathrm{FEV}_{1}$ slightly above baseline in patients with a high concentration of serum periostin ${ }^{26}$. Patients with a low concentration of serum periostin did not bene$\mathrm{fit}^{27}$, a finding which is in contrast to Noonan et al. ${ }^{58}$ who saw no improvement in $\mathrm{FEV}_{1}$ with lebrikizumab in individuals with a high concentration of serum periostin and only a minor increase in those with low periostin concentration.

In two trials where exacerbations were a primary endpoint, lebrikizumab reduced the rate of asthma exacerbations in patients with uncontrolled asthma despite daily use of high-dose ICS and a second asthma controller. Again, in patients with high periostin expression, efficacy on exacerbations and lung function was increased ${ }^{43}$. There was also an 
improvement in $\mathrm{FEV}_{1}$ in patients with high periostin expression who were treated with lebrikizumab. However, due to a problem with the study, treatment was discontinued and only treatment of 24 weeks could be analysed ${ }^{43}$.

Tralokinumab (MedImmune, UK) is an IgG4 monoclonal antibody that neutralises IL-13 and blocks the binding of IL-13 to IL-13R $\alpha 1$ and IL-13R $\alpha 2$. Tralokinumab did not improve symptoms in patients with moderate-to-severe uncontrolled asthma, but improved the $\mathrm{FEV}_{1}$ marginally compared to placebo, with greater effects in patients with detectable sputum IL-13 concentrations ${ }^{44}$. In patients with uncontrolled asthma on high-dose inhaled ICS and LABA, tralokinumab had no effect on exacerbation rates. Only subgroup analyses showed a trend towards a reduction in exacerbations in selected subjects, with high serum concentrations of periostin in particular ${ }^{45}$. Patient-related outcomes were only marginally improved and effects were variable.

Finally, GSK679586 (GlaxoSmithKline, UK) blocks the binding of IL-13 to IL-13R $\alpha 1$. Treatment with GSK679586 during a three-month period was disappointing and did not result in clinically meaningful improvements in asthma control, pulmonary function, or exacerbations in patients with severe asthma compared with placebo, according to a recent study ${ }^{46}$.

\section{Targeting interleukin 5}

\section{ANTI-INTERLEUKIN-5 ANTIBODY AND ANTI-INTERLEUKIN-5 RECEPTOR ANTIBODY}

Interleukin-5 is produced by Th2 cells and ILC2 and specifically targeted at eosinophils, facilitating their terminal differentiation and maturation. Interleukin-5 mobilises eosinophils and eosinophil precursors into the circulation and primes eosinophils for increased survival and increased cytotoxicity.

Mepolizumab (GlaxoSmithKline, UK) is a humanised anti-IL-5 monoclonal IgG1 antibody. In initial studies, mepolizumab reduced sputum and blood eosinophil counts compared to placebo ${ }^{20,47}$, but had no effect on response after allergen challenge. In a cohort of adults with moderately severe asthma recruited on the basis of asthma severity, mepolizumab showed no efficacy on symptom control or exacerbations ${ }^{20}$. In later studies and in specific cohorts of patients with (i) severe asthma on a combination of ICS and LABA, and (ii) with a history of exacerbations, and (iii) persistent sputum or blood eosinophilia, mepolizumab showed efficacy with decreased exacerbations in particular ${ }^{48,49,59}$. In a further phase II study in patients with recurrent severe asthma exacerbations and eosinophilic inflammation, mepolizumab was effective in reducing exacerbation rates, but did not improve $\mathrm{FEV}_{1}$ or quality of life $\mathrm{e}^{21}$. In this particular study, a blood eosinophil count of $\geq 150$ cells/ $\mu$ l was associated with a reduction in exacerbation rate of $72 \%$ compared with a reduction of $30 \%$ in those with a blood eosinophil count of $<150$ cells $/ \mu 1^{25}$.

In patients with recurrent exacerbations of asthma (more than two exacerbations per year) despite high-dose ICS and eosinophilic inflammation ( $>300$ cells/ $\mu$ l blood in the past year), use of mepolizumab led to a substantial reduction in exacerbations and improved asthma control and lung function ${ }^{50,51}$. Additionally, in patients with severe eosinophilic asthma on oral corticosteroid therapy, a median 
reduction in corticosteroid dose of $50 \%$ from baseline in the mepolizumab group compared with no reduction in the placebo group was achieved. This reduction in corticosteroid dose was accompanied by a reduction in the rate of exacerbations and in asthma symptoms as measured on ACQ- $5^{51}$. However, not all patients in this study responded to mepolizumab, and $36 \%$ of patients treated with mepolizumab could not reduce their oral corticosteroid dose.

Reslizumab (TEVA, US) is an IgG4 $\kappa$ humanised monoclonal antibody against IL-5. In patients with severe asthma on ICS/LABA and with sputum eosinophilia of more than $3 \%$, reslizumab improved asthma control and $\mathrm{FEV}_{1}$ with a trend towards fewer exacerbations than in those receiving placebo ${ }^{57}$. The phase III study program in patients inadequately controlled on ICS and with a blood eosinophil count $>400$ cells $/ \mu$ l and one or more exacerbations in the previous year, reslizumab significantly reduced the frequency of exacerbations compared with placebo ${ }^{52,53}$ with an accompanying improvement in lung function and symptoms.

Benralizumab (MedImmune, UK) also targets the IL-5 pathway, but this antibody is directed against the $\alpha$ chain of the IL- 5 receptor and there is some evidence for amplification of eosinophil apoptosis with this drug ${ }^{60}$. In patients with uncontrolled asthma using medium-to-high-dose ICS, frequent exacerbations, and with sputum eosinophilia, subcutaneous benralizumab at 20 or $100 \mathrm{mg}$ doses reduced asthma exacerbations by 36 and $41 \%{ }^{54}$. Patients receiving benralizumab also had small improvements in mean lung function and symptoms. This finding was supported by results from a very recent study in which acutely sick asthma patients received a single infusion of benralizumab, resulting in a reduced asthma exacerbation rate by $49 \%$ and exacerbation needing hospital admission by $60 \% 55,60$.

\section{ANTI-THYMIC STROMAL-DERIVED LYMPHOPOIETIN ANTIBODY}

Thymic stromal-derived lymphopoietin (TSLP) is a cytokine secreted by airway epithelial cells upon allergen and environmental exposure $^{61}$; it activates dendritic cells which recruit and activate Th2 cells, and is related to IL-7 ${ }^{62}$. In patients with severe asthma, TSLPs are increased in the airway epithelium ${ }^{63}$. The TSLP is also potentially involved in airway wall remodelling since it acts on fibroblasts ${ }^{64}$.

AMG 157 (Amgen, US), a human anti-TSLP monoclonal antibody, attenuated allergen-induced early and late asthmatic responses in mild allergic asthma and reduced blood and sputum eosinophil counts before and after the allergen challenge in one single recent study so far. It also affected fractional exhaled nitric oxide concentrations ${ }^{65}$.

\section{ANTAGONISTS OF CHEMOATTRACTANT RECEPTOR-HOMOLOGOUS MOLECULE EXPRESSED ON T HELPER TYPE 2 CELLS}

Prostaglandin D2 is released during allergen-induced reactions in the airways. This prostanoid activates a G-protein-coupled receptor, called chemoattractant receptor-homologous molecule expressed on Th2 cells (CRTH2 or DP2 receptor) present on a variety of cells ${ }^{66}$. Production of Th2-type cytokines by ILC2 is also stimulated 
by prostaglandin $\mathrm{D} 2$ via activation of its CRTH2 receptor $^{24}$ and also by leukotriene D4 (LTD4) ${ }^{25}$.

One CRTH2 antagonist, OC000459 (Oxagen, $\mathrm{UK}$ ), improved $\mathrm{FEV}_{1}$, asthma-related quality of life scores, and night-time symptoms, without affecting sputum eosinophil counts compared with placebo in patients with moderate persistent asthma not on ICS ${ }^{67}$. Another antagonist, AMG 853 (Amgen, US), used as an add-on to ICS therapy, did not show efficacy in patients with uncontrolled moderate-to-severe disease ${ }^{68}$, while the CRTH2 antagonist BI671800 (Boehringer Ingelheim, Germany) caused a small improvement in $\mathrm{FEV}_{1}$ in relatively mild patients without previous controller use and in patients on ICS ${ }^{69}$. A phase IIa study in mild-to-severe asthma with sputum eosinophilia, treatment with the CRTH2 antagonist QAW039 (Novartis, Switzerland) resulted in a three to fivefold reduction in sputum eosinophil count compared with placebo and a two to threefold reduction in eosinophil count in bronchial biopsies ${ }^{70}$ and a mild symptomatic benefit.

\section{Targeting non-T helper type 2-targets}

The CD4 T-cells that express interleukin in its different forms are termed Th17 cells. They mediate neutrophil activation via the production of the chemokines CXCL1 and CXCL8 from structural cells such as epithelial cells ${ }^{71}$. The Th17-mediated airway inflammation in asthma can be triggered by a variety of stimuli, including pollutants ${ }^{72,73}$. Over-expression of IL-17A and IL-17F can be found in the lungs of patients with neutrophilic corticosteroid-resistant disease, with expression levels correlating with asthma severity ${ }^{71}$.
A human anti-IL-17RA monoclonal antibody (Brodalumab; Amgen, US) did not affect asthma control scores, symptom-free days, or lung function in patients with inadequately controlled moderate-to-severe asthma who were on ICS therapy. Analysis of pre-specified patient subgroups seemed to show a high-reversibility responder subgroup ${ }^{74}$. A follow-up phase IIb study with this phenotype was stopped, however, because of a reported lack of efficacy.

CXCL8 (IL-8) is a chemokine involved in the chemo-attraction and activation of neutrophils through the CXCR2 receptor. SCH527123 (Merck, US), a CXCR2 antagonist, inhibited ozone-induced sputum neutrophilia in patients without asthma ${ }^{75}$. Its efficacy in severe asthma was more variable, with a reduction of sputum neutrophilia in adults, a modest reduction in mild exacerbations only, and no improvement in asthma control ${ }^{76}$.

Tumour necrosis factor- $\alpha$ (TNF- $\alpha$ ) is a pro-inflammatory Th1 cytokine that has been implicated in severe asthma through its effects on airway inflammation, hyper-responsiveness, and mucus hypersecretion. In two small, placebo-controlled, double-blind, crossover studies of patients with corticosteroid-refractory asthma, treatment with etanercept (Pfizer, US) (a soluble recombinant antibody) resulted in some clinical improvements in bronchial hyper-reactivity, quality of life scores, lung function reductions and the use of nebulised $\beta_{2}$ agonists $^{77,78}$. However, a subsequent larger study in adults with severe persistent asthma with the anti-TNF- $\alpha$ antibody golimumab (Centocor, US) had no overall beneficial effects ${ }^{79}$. Serious side effects included an increased frequency of 
infections and malignancies compared with placebo, and the program was discontinued for this indication.

\section{CONCLUDING REMARKS AND OUTLOOK}

Anti-inflammatory treatment of asthma will also in the future represent the core of asthma management, largely irrespective of clinical severity. Over the last couple of years a promising number of truly novel anti-inflammatory medications have emerged, enabling patient-specific pharmacotherapy based on molecular phenotyping or endotyping. Out of these, blockade of the effects of IL-5 with monoclonal antibodies directed towards IL-5 or its receptor, in patients with severe asthma with eosinophilia in blood or sputum, leads to a reduction in asthma exacerbation rates and an improvement in lung function and asthma control. Blocking the effects of IL-13 with anti-IL-13 antibody has been shown to lead to an improvement in lung function, probably associated with elevated serum concentration of periostin, but curiously, a reduction in exacerbations was only shown with one antibody (lebrikizumab), but not with another (tralokinumab). Dupilumab, which blocks the effects of IL-4 and IL-13 at receptor level, reduced exacerbations irrespective of baseline eosinophil count, improved lung function in patients with elevated blood eosinophil count, and reduced serum IgE concentrations.

The European Medicine Agency (EMA) and the US Food and Drug Administration (FDA) recently have given positive recommendations for use of mepolizumab as an add-on maintenance treatment in patients aged 18 years or older with severe eosinophilic asthma. This development will surely prompt further drug applications for novel antibody based anti-inflammatory therapies for severe asthma.

Surely, future effectiveness of research will have to unravel how these novel treatments (including anti-IgE) should be used practically. So far, there are no direct comparisons of the effects of one antibody treatment against another, and a search for appropriate biomarkers such as eosinophils, IgE, or periostin or a combination of biomarkers that are available clinically and predict outcomes are needed.

The relevance of non-Th2 or low-Th2 endotypes remains at present unclear, primarily since drug development for this type of asthmatic inflammation has been considerably less successful. Sputum neutrophilia seems to be an indicator of a potentially diverse inflammatory pathway which is not sufficiently endotyped at present. Non-Th2 mechanisms seem linked to corticosteroid insensitivity, and might be induced by bacterial or viral infections but could co-exist with Th2 mechanisms.

So far, targeting the Th2 pathway has made antibody therapies against IL-4, IL-5, and IL13 a close reality, in particular for eosinophilic inflammation in asthma. These developments are welcome and promising as they might enable us to treat severe asthma in its diversity more effectively. What remains is the quest for a lead concept of how to treat airway inflammation in the paucicellular mucosa, the Th2 low asthmatic, and the patient that does not promptly respond to steroids. Hopefully, the imminent introduction of novel successful antibody therapies will prompt further research in some of these underserved forms of asthma endotypes. 


\section{DECLARATION OF INTEREST}

\author{
Professor Rabe has been consulting, participat- \\ ed in Advisory Board Meetings, and received \\ lecture fees from AstraZeneca, Boehringer, \\ Chiesi, GSK, Novartis, Pearl, Roche, Sanofi and \\ Takeda. However, he holds no stock or other \\ equities in pharmaceutical companies and has \\ no links to the tobacco industry.
}

\section{ACKNOWLEDGEMENTS:}

I am the sole author of this manuscript and no external editorial help was sought. I acknowledge in particular the work by BN Lambrecht and H Hammad, KF Chung, and J Fahy whose very recent reviews have provided an important source of information for the presented review manuscript.

\section{REFERENCES}

1. Global Asthma Network. Global asthma report 2014. Global burden of disease due to asthma. Available at: http: / www.globalasthmareport.org/ burden/burden.php (Accessed November 23, 2015).

2. Lambrecht BN, Hammad H. The immunology of asthma. Nature Immunol. 2015;16:45-56.

3. Global Initiative for Asthma. Global strategy for asthma management and prevention. 2015. Available at: http:/ / www.ginasthma.org/ documents / 4 (Accessed November 23, 2015).

4. Chung KF, Wenzel SE, Brozek JL et al. International ERS/ATS guidelines on definition, evaluation and treatment of severe asthma. Eur Respir J. 2014;43:343-73.

5. Moore WC, Bleecker ER, Curran-Everett D et al. National Heart, Lung, Blood Institute's Severe Asthma Research Program. Characterization of the severe asthma phenotype by the National Heart, Lung, and Blood Institute's Severe Asthma Research Program. J Allergy Clin Immunol. 2007;119:405-13.

6. European Network for Understanding Mechanisms of Severe Asthma. The ENFUMOSA cross-sectional European multicentre study of the clinical phenotype of chronic severe asthma. Eur Respir J. 2003;22:470-7.

7. Adcock IM, Caramori G, Chung KF. New targets for drug development in asthma. Lancet. 2008;372:1073-87.

8. Lambrecht BN, Hammad H. Allergens and the airway epithelium response: gateway to allergic sensitization. J Allergy Clin Immunol. 2014;134:499-507.

9. Holgate ST. Innate and adaptive immune responses in asthma. Nat Med. 2012;18:673-83.

10. Erle DJ, Sheppard D. The cell biology of asthma. J Cell Biol. 2014;205:621-31.

11. Chung KF. Targeting the interleukin pathway in the treatment of asthma. Lancet. 2015;386:1086-96.
12. Schuijs MJ, Willart MA, Hammad $\mathrm{H}$ et al. Cytokine targets in airway inflammation. Curr Opin Pharmacol. 2013;13:351-61.

13. Moore WC, Meyers DA, Wenzel SE et al. National Heart, Lung, and Blood Institute's Severe Asthma Research Program. Identification of asthma phenotypes using cluster analysis in the Severe Asthma Research Program. Am J Respir Crit Care Med. 2010;181:315-23.

14. Fahy JV. Type 2 inflammation in asthma - present in most, absent in many Nat Rev Immunol. 2015;15:57-65.

15. Chung KF, Adcock IM. How variability in clinical phenotypes should guide research into disease mechanisms in asthma. Ann Am Thorac Soc 2013;10(Suppl):S109-17.

16. Woodruff PG, Boushey HA, Dolganov GM et al. Genome-wide profiling identifies epithelial cell genes associated with asthma and with treatment response to corticosteroids. Proc Natl Acad Sci USA. 2007;104:15858-63.

17. Woodruff PG, Modrek B, Choy DF et al. T-helper type 2-driven inflammation defines major subphenotypes of asthma. Am J Respir Crit Care Med. 2009;180:388-95.

18. Wenzel SE. Asthma phenotypes: the evolution from clinical to molecular approaches. Nat Med. 2012;18:716-25.

19. Chung KF. Asthma phenotyping: a necessity for improved therapeutic precision and new targeted therapies. J Intern Med. 2015. [Epub ahead of print].

20. Flood-Page P, Swenson C, Faiferman I et al. International Mepolizumab Study Group. A study to evaluate safety and efficacy of mepolizumab in patients with moderate persistent asthma. Am J Respir Crit Care Med 2007;176:1062-71.

21. Pavord ID, Korn S, Howarth P et al. Mepolizumab for severe eosinophilic asthma (DREAM): a multicentre, double-blind, placebo-controlled trial. Lancet. 2012;380:651-59.

22. Krug N, Hohlfeld JM, Kirsten AM et al., Allergen-induced asthmatic responses modified by a GATA3-specific DNAzyme. N Engl J Med. 2015;372:1987-95.

23. Wagener AH, de Nijs SB, Lutter R et al. External validation of blood eosinophils, FE(NO) and serum periostin as surrogates for sputum eosinophils in asthma. Thorax. 2015;70:115-20.

24. Peters MC, Mekonnen ZK, Yuan S et al. Measures of gene expression in sputum cells can identify $\mathrm{T}_{\mathrm{H}}$ 2-high and $\mathrm{T}_{\mathrm{H}}$ 2-low subtypes of asthma. J Allergy Clin Immunol. 2014;133:38894.

25. Katz LE, Gleich GJ, Hartley BF et al. Blood eosinophil count is a useful biomarker to identify patients with severe eosinophilic asthma. Ann Am Thorac Soc. 2014;11:531-6.

26. Jia G, Erickson RW, Choy DF et al. Periostin is a systemic biomarker of eosinophilic airway inflammation in asthmatic patients. J Allergy Clin Immunol. 2012;130:647-54.

27. Corren J, Lemanske RF, Hanania NA et al. Lebrikizumab treatment in adults with asthma. N Engl J Med. 2011;365:1088-98.

28. Lloyd CM, Saglani S. Epithelial cytokines and pulmonary allergic inflam mation. Curr Opin Immunol. 2015;34:52-8.

29. Licona-Limón $\mathrm{P}$, Kim LK, Palm NW et al. $\mathrm{T}_{\mathrm{H}} 2$, allergy and group 2 innate lymphoid cells. Nat Immunol. 2013;14:536-42.

30. Djukanović R, Wilson SJ, Kraft M et al. Effects of treatment with anti-immunoglobulin E antibody omalizumab on airway inflammation in allergic asthma. Am J Respir Crit Care Med. 2004;170:583-93.

31. van Rensen EL, Evertse CE, van Schadewijk WA et al. Eosinophils in bronchial mucosa of asthmatics after allergen challenge: effect of anti-IgE treatment. Allergy. 2009;64:72-80.

32. Normansell R, Walker S, Milan SJ et al. Omalizumab for asthma in adults and children. Cochrane Database Syst Rev. 2014;1:CD003559.

33. Hanania NA, Wenzel S, Rosén K et al. Exploring the effects of omalizumab in allergic asthma: an analysis of biomarkers in the EXTRA study. Am J Respir Crit Care Med. 2013;187:804-11.

34. Arm JP, Bottoli I, Skerjanec A et al. Pharmacokinetics, pharmacodynamics and safety of QGE031 (ligelizumab), a novel high-affinity anti-IgE antibody, in atopic subjects. Clin Exp Allergy. 2014;44:1371-85.

35. Maes T, Joos GF, Brusselle GG. Targeting interleukin-4 in asthma: lost in translation? Am J Respir Cell Mol Biol. 2012;47:261-70. 
36. Wills-Karp M, Luyimbazi J, Xu X et al. Interleukin-13: central mediator of allergic asthma. Science. 1998;282:2258-61.

37. Wenzel S, Wilbraham D, Fuller R et al. Effect of an interleukin-4 variant on late phase asthmatic response to allergen challenge in asthmatic patients: results of two phase 2a studies. Lancet. 2007;370:1422-31.

38. Slager RE, Otulana BA, Hawkins GA et al. IL-4 receptor polymorphisms predict reduction in asthma exacerbations during response to an anti-IL-4 receptor alpha antagonist. J Allergy Clin Immunol. 2012;130:516-22.

39. Corren J, Busse W, Meltzer EO et al. A randomized, controlled, phase 2 study of AMG 317, an IL-4R alpha antagonist, in patients with asthma. Am J Respir Crit Care Med. 2010;181:788-96.

40. Wenzel S, Ford L, Pearlman D et al. Dupilumab in persistent asthma with elevated eosinophil levels. N Engl J Med. 2013;368:2455-66.

41. Wenzel SE, Wang L, Pirozzi G et al. Dupilumab improves lung function and reduces severe exacerbations in uncontrolled asthmatics with baseline eosinophil levels above and below 300 cells / $\mu 1$. 2015 Meeting of the American Thoracic Society; Denver, CO, USA; May 2015. [Abstract A6362].

42. Scheerens H, Arron JR, Zheng Y et al. The effects of lebrikizumab in patients with mild asthma following whole lung allergen challenge. Clin Exp Allergy. 2014;44:38-46.

43. Hanania NA, Noonan M, Corren J et al. Lebrikizumab in moderate-to-severe asthma: pooled data from two randomised placebo-controlled studies. Thorax. 2015;70:748-56.

44. Piper E, Brightling C, Niven R et al. A phase II placebo-controlled study of tralokinumab in moderate-to-severe asthma. Eur Respir J. 2013;41:330-8.

45. Brightling CE, Chanez P, Leigh R et al. Efficacy and safety of tralokinumab in patients with severe uncontrolled asthma: a randomised, double-blind, placebo-controlled, phase 2b trial. Lancet Respir Med. 2015;3:692-701.

46. De Boever EH, Ashman C, Cahn AP et al. Efficacy and safety of an antiIL-13 mAb in patients with severe asthma: a randomized trial. J Allergy Clin Immunol. 2014;133:989-96.

47. Leckie MJ, ten Brinke A, Khan J et al. Effects of an interleukin-5 blocking monoclonal antibody on eosinophils, airway hyper-responsiveness, and the late asthmatic response. Lancet. 2000;356:2144-8.

48. Haldar P, Brightling CE, Hargadon B et al. Mepolizumab and exacerbations of refractory eosinophilic asthma. N Engl J Med. 2009;360:973-84.

49. Nair P, Pizzichini MM, Kjarsgaard M et al. Mepolizumab for prednisone-dependent asthma with sputum eosinophilia. N Engl J Med. 2009;360:985-93.

50. Ortega HG, Liu MC, Pavord ID et al. MENSA Investigators. Mepolizumab treatment in patients with severe eosinophilic asthma. N Engl J Med. 2014; 371:1198-207.

51. Bel EH, Wenzel SE, Thompson PJ et al, and the SIRIUS Investigators. Oral glucocorticoid-sparing effect of mepolizumab in eosinophilic asthma. N Engl J Med. 2014;371:1189-97.

52. Castro M, Mathur S, Hargreave F et al. Res-5-0010 Study Group. Reslizumab for poorly controlled, eosinophilic asthma: a randomized, placebo-controlled study. Am J Respir Crit Care Med. 2011;184:1125-32.

53. Castro M, Zangrilli J, Wechsler ME et al. Reslizumab for inadequately controlled asthma with elevated blood eosinophil counts: results from two multicentre, parallel, double-blind, randomised, placebo-controlled, phase 3 trials. Lancet Respir Med. 2015;3:355-66.

54. Castro M, Wenzel SE, Bleecker ER et al. Benralizumab, an anti-interleukin 5 receptor $\alpha$ monoclonal antibody, versus placebo for uncontrolled eosinophilic asthma: a phase $2 \mathrm{~b}$ randomised dose-ranging study. Lancet Respir Med. 2014;2:879-90

55. Nowak RM, Parker JM, Silverman RA et al. A randomized trial of benralizumab, an antiinterleukin 5 receptor $\alpha$ monoclonal antibody, after acute asthma. Am J Emerg Med. 2015;33:14-20.

56. Borish LC, Nelson HS, Lanz MJ et al. Interleukin-4 receptor in moderate atopic asthma. A phase I/II randomized, placebo-controlled trial. Am J Respir Crit Care Med. 1999;160:1816-23.

57. Borish LC, Nelson HS, Corren J et al. IL-4R Asthma Study Group. Efficacy of soluble IL-4 receptor for the treatment of adults with asthma. J Allergy Clin Immunol. 2001;107:963-70.
58. Noonan M, Korenblat P, Mosesova S et al. Dose-ranging study of lebrikizumab in asthmatic patients not receiving inhaled steroids. J Allergy Clin Immunol. 2013;132:567-74.

59. Nair P. Anti-interleukin-5 monoclonal antibody to treat severe eosinophilic asthma. N Engl J Med. 2014;371:1249-51.

60. Kolbeck R, Kozhich A, Koike M et al. MEDI-563, a humanized anti-IL-5 receptor alpha $\mathrm{mAb}$ with enhanced antibody-dependent cell-mediated cytotoxicity function. J Allergy Clin Immunol. 2010;125:1344-53.

61. Kouzaki H, O'Grady SM, Lawrence CB et al. Proteases induce production of thymic stromal lymphopoietin by airway epithelial cells through protease-activated receptor-2. J Immunol. 2009;183:1427-34.

62. Liu YJ, Soumelis V, Watanabe $\mathrm{N}$ et al. TSLP: an epithelial cell cytokine that regulates $\mathrm{T}$ cell differentiation by conditioning dendritic cell maturation. Annu Rev Immunol. 2007;25:193-219.

63. Préfontaine D, Nadigel J, Chouiali F et al. Increased IL-33 expression by epithelial cells in bronchial asthma. J Allergy Clin Immunol. 2010;125:752-54.

64. Wu J, Liu F, Zhao J et al. Thymic stromal lymphopoietin promotes asthmatic airway remodelling in human lung fibroblast cells through STAT3 sig nalling pathway. Cell Biochem Funct. 2013;31:496-503.

65. Gauvreau GM, O’Byrne PM, Boulet LP et al. Effects of an anti-TSLP antibody on allergen-induced asthmatic responses. N Engl J Med. 2014;370:2102-10.

66. Pettipher R, Hansel TT, Armer R. Antagonism of the prostaglandin D2 receptors DP1 and $\mathrm{CRT}_{\mathrm{H}} 2$ as an approach to treat allergic diseases. Nat Rev Drug Discov. 2007;6:313-25.

67. Barnes N, Pavord I, Chuchalin A et al. A randomized, double-blind, placebo-controlled study of the $\mathrm{CRT}_{\mathrm{H}} 2$ antagonist OC000459 in moderate persistent asthma. Clin Exp Allergy. 2012;42:38-48.

68. Busse WW, Wenzel SE, Meltzer EO et al. Safety and efficacy of the prostaglandin D2 receptor antagonist AMG 853 in asthmatic patients. J Allergy Clin Immunol. 2013;131:339-45.

69. Hall IP, Fowler AV, Gupta A et al. Efficacy of BI 671800, an oral CRT $\mathrm{H}_{\mathrm{H}} 2$ antagonist, in poorly controlled asthma as sole controller and in the presence of inhaled corticosteroid treatment. Pulm Pharmacol Ther. 2015;32:37-44.

70. Berair RGS, Singapuri A, Hartley R et al. Effect of QAW039, an oral prostaglandin $\mathrm{D} 2$ receptor $\left(\mathrm{DP} 2 / \mathrm{CrT}_{\mathrm{H}} 2\right)$ antagonist upon sputum and bronchial eosinophilic inflammation and clinical outcomes in treatment-resistant asthma: a phase 2a randomised placebo-controlled trial. 2015 Meeting of the American Thoracic Society; Denver, CO, USA; 2015. [Abstract A6361].

71. Roussel L, Houle F, Chan C et al. IL-17 promotes p38 MAPK-dependen endothelial activation enhancing neutrophil recruitment to sites of inflammation. J Immunol. 2010;184:4531-7.

72. Vroman H, van den Blink B, Kool M. Mode of dendritic cell activation: the decisive hand in $\mathrm{T}_{\mathrm{H}} 2$ /Th17 cell differentiation. Implications in asthma severity? Immunobiology. 2015;220:254-61.

73. Al-Ramli W, Préfontaine D, Chouiali F et al. T(H)17-associated cytokines (IL-17A and IL-17F) in severe asthma. J Allergy Clin Immunol. 2009;123:1185-7.

74. Busse WW, Holgate S, Kerwin E et al. Randomized, double-blind, placebo-controlled study of brodalumab, a human anti-IL-17 receptor monoclonal antibody, in moderate to severe asthma. Am J Respir Crit Care Med. 2013;188:1294-302.

75. Holz O, Khalilieh S, Ludwig-Sengpiel A et al. SCH527123, a novel CXCR2 antagonist, inhibits ozone-induced neutrophilia in healthy subjects. Eur Respir J. 2010;35:564-70.

76. Nair P, Gaga M, Zervas E et al. Study Investigators. Safety and efficacy of CXCR2 antagonist in patients with severe asthma and sputum neutrophils: a randomized, placebo-controlled clinical trial. Clin Exp Allergy. 2012;42:1097-103.

77. Berry MA, Hargadon B, Shelley M et al. Evidence of a role of tumor necrosis factor alpha in refractory asthma. N Engl J Med. 2006;354:697-708.

78. Morjaria JB, Chauhan AJ, Babu KS et al. The role of a soluble TNFalpha receptor fusion protein (etanercept) in corticosteroid refractory asthma: a double blind, randomised, placebo controlled trial. Thorax. 2008;63:584-91.

79. Wenzel SE, Barnes PJ, Bleecker ER et al, and the T03 Asthma Investigators. A randomized, double-blind, placebo-controlled study of tumor necrosis factor-alpha blockade in severe persistent asthma. Am J Respir Crit Care Med. 2009:179:549-58. 